\title{
Piezoelectric Quartz Crystal Sensors Applied for Bioanalytical Assays and Characterization of Affinity Interactions
}

\author{
Petr Skládal \\ Department of Biochemistry, Masaryk University, Kotláéská 2, 61137 Brno, Czech Republic
}

\begin{abstract}
Esta revisão apresenta cristais piezoeletricos de quartzo como transductores aplicáveis no desenvolvimento de diferentes tipos de ensaios bioanaliticos. Os componentes do sistema de medidas para sensores tipo piezo são descritos juntamente com os sistemas de equipamentos comerciais existentes. Os biosensores piezo elétricos podem ser aplicados para determinação de vírus, bacteriais e outras células, proteínas, ácidos nucléicos e pequenas moléculas encontradas em remédios, hormônios e pesticidas. Além de mudança de massa, alguns ensaios de aglutinação empregando efeitos de viscosidade são discutidos. Finalmente, o monitoramento da afinidade das interações direto semmarcação e em tempo real usando sensores piezo é apresentado. Os pressupostos teóricos para a determinação apropriada das constantes de velocidade e de equilíbrio são apresentados e uma aproximação é demonstrada para a interação anticorpo com o correspondente antígeno (proteína secalin). Vários exemplos de estudo de afinidade são mostrados, incluindo a interação de proteínas (anticorpos e antígenos), de ácidos nucléicos (hibridização, intercalação de complexos metálicos), lipídeos e camadas com base de sacarídeos.
\end{abstract}

This review presents piezoelectric quartz crystals as transducers suitable for development of different types of bioanalytical assays. The components of measuring systems for piezosensors are described together with providers of commercial equipment. The piezoelectric biosensors are summarized for determination of viruses, bacterial and other cells, proteins, nucleic acids and small molecules as drugs, hormones and pesticides. In addition to mass changes, some agglutination assays employing viscosity effects are addressed. Finally, the direct label-free and real-time monitoring of affinity interactions using piezosensors is presented. The theoretical background for determination of appropriate kinetic rate and equilibrium constants is shown and the approach is demonstrated on the interaction of antibody with the corresponding antigen (protein secalin). Several examples of affinity studies are provided, including interactions of proteins (antibody and antigens, receptors and ligands), nucleic acids (hybridization, intercalation of metal complexes), lipids and saccharide-based layers.

Keywords: piezoelectric quartz crystal sensor, piezoelectric immunosensors, affinity interactions, kinetic parameters

\section{Introduction}

Affinity interactions - formation of biocomplexes including antigen - antibody, protein - nucleic acid, hybridization of complementary strands of ssDNA, chemoreceptor - ligand etc., represent the most important biochemical processes involved in nature. This principle is also widely employed for design of bioanalytical assays. For this reason, a significant effort is devoted in detailed study and quantitative characterization of the underlying binding reaction. The direct methods for real-time

\footnotetext{
*e-mail: skladal@chemi.muni.cz
}

monitoring of bioaffinity interactions employ much simplified assay formats compared to the traditional approaches based on labels as enzymes, fluorophores and radioactivity. The continuous evaluation of the progress of interaction provides more detailed information compared to label-based techniques, which measure the amount of the bound label only at the end of the binding process. In addition, the direct affinity sensors can be used repeatedly for many assays. Several physical transducers are capable of measuring surface mass changes resulting from the formation of biocomplexes at the sensitive area. Although mostly advanced optical systems are utilized, the piezoelectric and acoustic devices ${ }^{1}$ represent similar but significantly less expensive alternative. This review 
should provide a better insight into piezoelectric sensors with respect to bioanalytical applications.

Several anisotropic crystals exhibit piezoelectric effect - mechanical deformation of such crystals generates oriented dipoles and electric voltage. In the opposite, alternating voltage applied on such crystals excites vibrations. At resonance frequency equal to the natural frequency of vibration, transfer of energy from the electric field to the crystal is most efficient and the energy remains conserved in the oscillating system. The typical piezoelectric quartz crystal is shown together with scheme of the shear horizontal vibration (Figure 1). A thin plate of quartz (AT-cut) is coated with metal electrodes on both sides. The plate is usually inserted in a holder for simplified manipulation and connection to measuring systems.
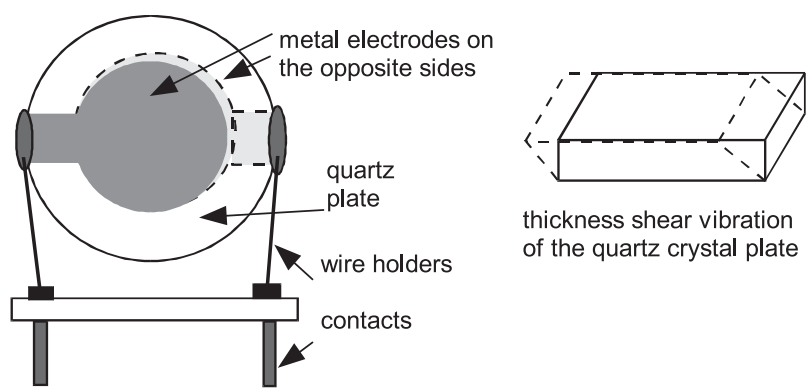

thickness shear vibration of the quartz crystal plate

Figure 1. Piezoelectric quartz crystal microbalance and scheme of vibrations.

The piezoelectric transducers are being used as chemical sensors since discovery of the relationship between mass of adsorbed rigid films and the resonant frequency changes by Sauerbrey: ${ }^{2}$

$\Delta f=-\frac{2 f_{0}^{2} \Delta m}{A \sqrt{\rho_{q} \mu_{q}}}=-2.26 \cdot 10^{6} f_{0}^{2} \frac{\Delta m}{A}$

The change $\Delta f$ of the resonant frequency $f_{0}$ of the piezoelectric crystal is directly proportional to the mass change $\Delta m$, the numeric constant applies to calculations using $\Delta f$ in $\mathrm{Hz}, f_{0}$ in $\mathrm{MHz}$ and $\Delta m$ in $\mathrm{g} / \mathrm{cm}^{2}$. The system functions as a sensitive quartz crystal microbalance (QCM); improved sensitivity of recent devices resulted in the alternative name "nanobalance". In this way, the amount of molecules bound on the sensitive area of electrodes can be easily quantitatively measured as a decrease of the resonant frequency.

\section{Measuring System for Piezosensors}

The piezoelectric crystals with gold electrodes and the basic resonant frequency of $10 \mathrm{MHz}$ are the most common ones, though crystals with higher frequencies (up to $27 \mathrm{MHz}$ ) will provide a higher sensitivity according to equation (1). Higher frequencies are not routinely used as the quartz plates become too thin and fragile. Piezoelectric crystals, oscillators and other instrumentation for microbalance might be obtained from several companies: International Crystal Manufacturing, Oklahoma City, OK (ICM, http://www.icmfg.com); Universal Sensors, Metairie, LA (http://intel.ucc.ie/sensors/universal/); Seiko / EG\&G, Japan; Q-Sense, Göteborg, Sweden (http://www.qsense.com); Elchema, Potsdam, NY; CH Instruments, Austin, TX (http://chinstruments.com). Comparison of other piezoelectric devices was published in the literature. ${ }^{3}$

Measuring setup for affinity studies consists of the piezosensor, driving electronics and a flow-through system (Figure 2). The crystal is usually sandwiched between two soft rubber o-rings; reasonable force should be applied to prevent damage of thin and brittle crystals. Alternatively, the crystal might be attached with the help of glue (siliconbased) either to the bottom or sidewall of a suitable vessel equipped with stirring bar. Holders for crystals suitable for immersion in solution are also available. For all cell designs, one side of the crystal should only contact the working solutions. The flow delivery system consist of a peristaltic pump providing flow rates around 30 to $200 \mu \mathrm{L}$ $\mathrm{min}^{-1}$. Models with several rollers are preferred as the noise due to pulsation will be reduced. In addition, electronically controlled switching and/or multiposition valves and autosampler will enable automation of performance.

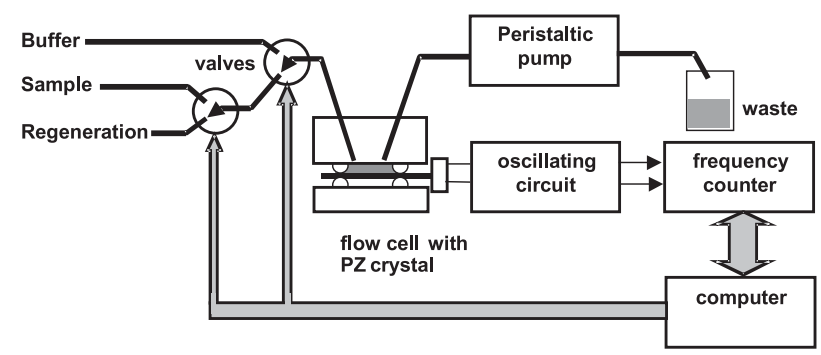

Figure 2. Example of a semiautomatic setup for measurements with piezoelectric immunosensors.

Oscillating circuit driving the crystal should provide enough energy to the crystal for smooth oscillation in the presence of liquid. The simplest constructions are based on the gate oscillator ${ }^{4}$ (the circuit 74LS01); the integrated form of this oscillator (74LS320, Figure 3) will provide much higher energy to the crystal resulting in improved performance under variable conditions. ${ }^{5}$ Better stability is obtained using carefully designed lever oscillators consisting of individual transistors (e.g. ICM). 


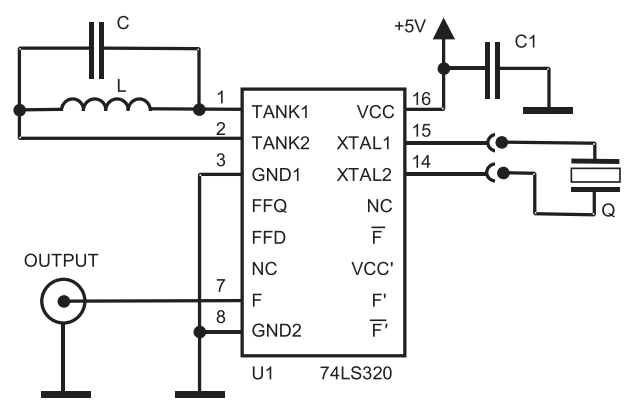

Figure 3. Oscillating circuit suitable for measurements with piezoelectric crystals (Q) in solutions. C1, capacitor $100 \mathrm{nF}$. The capacitor $\mathrm{C}$ and inductor $\mathrm{L}$ depend on the particular crystal, e.g. for $10 \mathrm{MHz}$ crystal the values should be close to $17 \mathrm{pF}$ and $15 \mu \mathrm{H}$, respectively. The resonance equation $\left(2 \pi f_{0}\right)^{-2}=\mathrm{LC}$ should be satisfied.

A counter for measuring changes of the resonant frequency can be a common device widely used in electronics. This simplest direct counting method offers resolution of $1 \mathrm{~Hz}$ within $1 \mathrm{sec}$, typically for the $10 \mathrm{MHz}$ crystals. To achieve better sensitivity, the output frequency from the oscillator is usually subtracted from a similar stable reference frequency and thus obtained low difference frequency signal (typically around $10 \mathrm{kHz}$ ) is further processed. One option (e.g. ELCHEMA) is to use a precise frequency to voltage converter, filter and fast highresolution $\mathrm{A} / \mathrm{D}$ converter to digitize the signal. Alternatively, the indirect counting approach can be chosen (e.g. $\mathrm{CH}$ Instruments) in which the lower experimental frequency is used as a clock signal for counting much higher stable frequency (tenths of megahertz). Both options provide a short measuring time $(1 \mathrm{~ms})$ and a resolution better than $0.1 \mathrm{~Hz}$. Most commercial systems are connected to a personal computer in order to allow on-line monitoring of the affinity interaction.

\section{Evaluation of Affinity Interactions}

\subsection{Theoretical model for determination of kinetic rate constants}

In addition to concentration measurements and combined electrochemical experiments, ${ }^{6}$ the piezosensors are also suitable for kinetic characterization of affinity binding reactions. Modification of the sensing area with biomolecules provides affinity biosensors; the immobilized ligand A forms affinity complex with the complementary partner B in solution and the associated surface mass changes are evaluated. Formation of the biocomplex $\mathrm{AB}$ at the surface of the piezoelectric crystal is characterized by the kinetic association $k_{a}$ and dissociation $k_{d}$ rate constants:

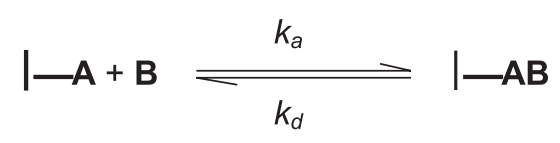

The rate of formation of the complex $d[\mathrm{AB}] / d t$ can be expressed using the measured frequency $f$ and concentration $c$ for the free partner B:

$d[\mathrm{AB}] / d t=-d f / d t=k_{a}\left(f_{\max }-f\right) c-k_{d} f$

The binding curves ( $f$ vs. $t$ dependencies) were usually transformed to obtain $d f / d t$ vs. $f$ plots that subsequently provide kinetic constants from equation ((2) using linear regression. ${ }^{7}$ A more elegant and precise method is integration of equation ((2) and then introduction of substitutions $f_{e q}$ and $k_{o b s}{ }^{8}$ The dependence of the resonant frequency $f$ on time $t$ can be fitted to the kinetic equation similarly as described for the optical biosensor systems: ${ }^{9}$

$f=\frac{k_{a} c f_{\max }}{k_{a} c+k_{d}}\left\{1-\exp \left[-\left(k_{a} c+k_{d}\right) t\right]\right\}=f_{e q}\left[1-\exp \left(-k_{o b s} t\right)\right]$

$c$ is concentration of the free partner $\mathrm{B}$ and $f_{\max }$ represents the capacity of the crystal (maximum change of frequency obtained after saturation of all binding sites). In this way, the binding curves can be directly used for calculation of parameters using non-linear regression. Plot of $k_{o b s}$ against concentration $c$ provides values of the rate constants. A typical affinity experiment with the piezoelectric immunosensor is schematically shown in Figure 4. Initially, a stable background signal $f_{0}$ is obtained in the presence of buffer. Then, sample solution containing the free partner B is injected - association phase. The biomolecules with free binding sites interact with the immobilized ligand A. A decrease of frequency is observed as surface mass on the

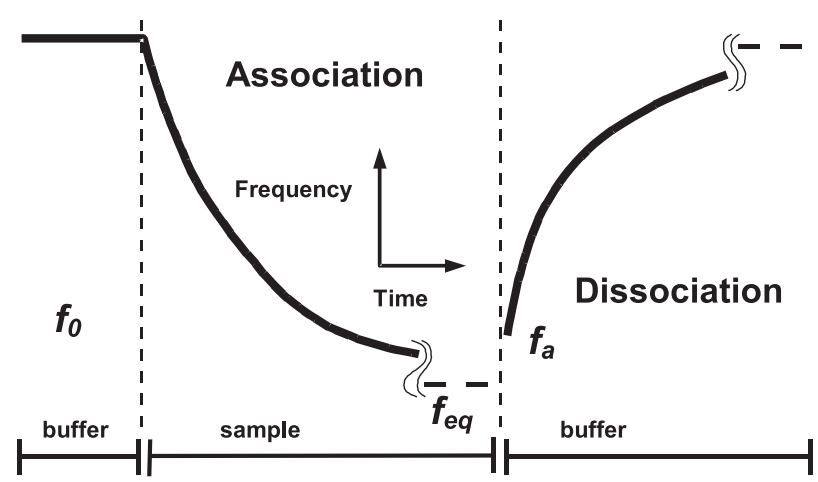

Figure 4. Characterization of kinetic properties of antibodies. First, the background signal is recorded in the carrier buffer only, association reaction in the presence of the sample follows - formation of immunocomplexes at the sensing surface, and finally spontaneous dissociation of immunocomplexes is observed in the absence of the sample. 
crystal increases and the equilibrium change $f_{e q}$ is eventually achieved. Then, buffer is injected again and the dissociation of immunocomplexes is observed. From this phase, the dissociation constant $k_{d}$ can be obtained independently, $f_{a}$ represents the amount of the surface-bound immunocomplex at the beginning of the dissociation:

$f=f_{a} \exp \left(-k_{d} t\right)$

\subsection{Example of characterization of anti-secaline antibody}

For a better understanding, the described model will be demonstrated on measurement of kinetic parameters for the monoclonal antibody prepared against the rye proteins secalins (kindly provided by the Institute of Food Research, Norwich, UK). The sensing surface of piezoelectric quartz crystal $(10 \mathrm{MHz})$ was silanized using $\gamma$ aminopropyltriethoxysilane and thus obtained amino group was used for covalent attachment of secalins using glutaraldehyde. Samples containing different concentrations of the studied antibody were allowed to interact with secaline-modified sensors placed in the flow-through cell, both association and dissociation phases were recorded and thus obtained signal traces are shown in Figure 5.

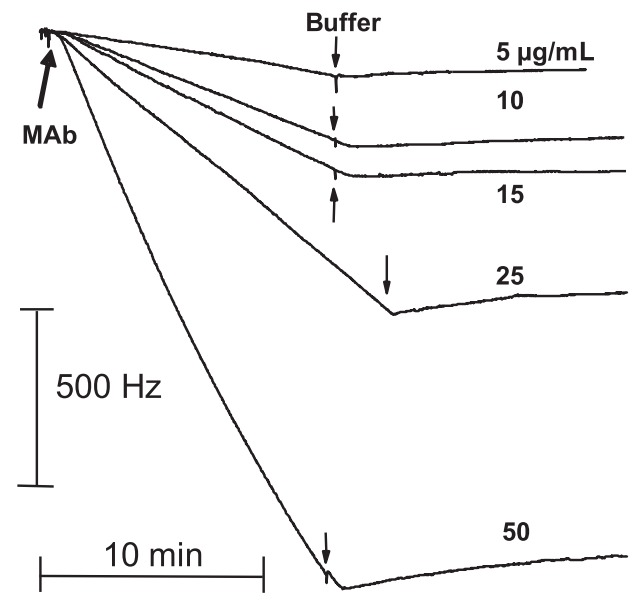

Figure 5. Experimental curves from the piezosensor analysis of antibody binding on the sensing surface with immobilized antigen secalins. The up arrow indicates beginning of flow of antibodies (association phase, concentrations of MAb are shown close to the curves), down arrows mark beginning of buffer flow only (dissociation phase). Flow-through setup, thin-layer flow cell $(25 \mu \mathrm{L}$ in-

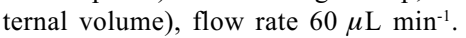

For each individual curve, the values of $k_{o b s}$ and $f_{e q}$ were determined using non-linear curve fitting of the frequency $f$ vs. time $t$ traces to equation (3). From the dissociation part of the traces, the values of $k_{d}$ were directly determined using non-linear regression and equation (4).
Plot of $k_{o b s}$ values against the corresponding concentrations $c$ of antibodies should provide linear dependence; substitution in equation ( $(3), k_{o b s}=k_{a} c+k_{d}$, where $k_{a}$ is equal to the slope and $k_{d}$ to the intercept. The $k_{o b s}$ vs. $c$ plot as well as the obtained values of constants are shown in Figure 6.



Figure 6. Plot of the $k_{o b s}$ constant obtained by non-linear fitting of the association parts of the binding curves against the corresponding concentrations of the antibody ( $M_{r}$ of antibody was assumed to be $160 \mathrm{kDa}$ ).

The determined values of constants should always be critically interpreted as these need not exactly agree with the corresponding values obtained from experiments with both affinity partners free in solution. The immobilization of small molecules (e.g. haptens) can affect the conformation. In addition, the density of ligands and mass transport effects should be considered, too. The ligand can be immobilized either as a single monolayer or inside a three-dimensional dextran matrix. The latter approach provides higher levels of signal; on the other hand, dissociation can be disturbed by "rebinding" effects.

\section{Immobilization of Biomolecules on Piezosensors}

The immobilization procedures suitable for piezosensors include quite different strategies ranging from simple physical adsorption to covalent binding on activating sublayers and finally even oriented attachment of biomolecules. The generally applicable immobilization procedures ${ }^{10}$ are suitable also for piezosensors; some published approaches ${ }^{11}$ will be mentioned in detail.

Before any covalent immobilization procedures, the inert surface of metal (mostly gold) electrodes deposited 
on the quartz plate of the sensor should be activated. In this way, silanization was widely used for activation, ${ }^{12}$ the suitable reagents include $\gamma$-aminopropyltriethoxysilane (APTS) providing amino groups and $\gamma$-glycidoxypropyltrimethoxypropane (GOPS) providing reactive oxirane groups. Thus modified surfaces are suitable either directly (GOPS) or after glutaraldehyde activation (APTS) for attachment of biomolecules with free amino groups (e.g. lysine residues from proteins).

Another popular approach employs thiocompounds (thiols and disulfides) irreversibly adsorbing on gold surfaces. Thus formed self-assembled monolayers ${ }^{13}$ are quite convenient for further immobilization steps. Thus, cystamine/cysteamine and $p$-aminothiophenol provide surface amino groups; thiopropionic acid, mercaptoundecanoic acid and lipoic acid result in available carboxyl groups. ${ }^{14}$ Special reagents as 3,3'-dithiodipropionic acid di(N-hydroxysuccinimide ester) (DTSP) attach on the surface and provide reactive NHS-groups suitable for immediate coupling of biomolecules with free amino groups.

From proteins, self-assembled layers of avidin (streptavidin) $)^{15}$ and protein A $(\mathrm{G})$ appear convenient for further immobilization steps. The self-assembling feature can be even implemented in recombinant proteins. Thus, self-assembled glutathione layer was further extended by binding of a chimerical protein consisting of calmodulin and glutathione-S-transferase. ${ }^{16}$ Spontaneous binding of protein $\mathrm{A}$ to gold was further enhanced by genetically inserting cysteine residue at the $\mathrm{C}$-end of the molecule. ${ }^{17}$

Thus obtained surfaces can be directly used for immobilization of bioligands in the form of a monolayer. Sometimes, hydrophilic layers (e.g. dextrans activated by periodate oxidation) are used to provide a thicker threedimensional matrix with much higher ligand coupling capacities. ${ }^{18}$ Similarly, the alternating protein polyelectrolyte multilayers were shown to provide increased response; poly(styrenesulfonate) was used together with immunoglobulin. ${ }^{19}$

Antibodies are probably the most often immobilized protein molecules. The oriented immobilization through protein A forming complex in the Fc part of antibody molecule remains the most convenient method. ${ }^{20}$ The protein A-antibody complex can be stabilized using dimethylpimelimidate in order to facilitate regeneration of the biosensing layer. Alternatively, surface oligosaccharides from the Fc part might be oxidized using periodate and thus activated antibody will be attached to surface with available amino groups. Immobilization of antibodies using adsorbed Langmuir-Blodgett method $^{21}$ does not seem to provide robust sensing interfaces. Linker lipids in a phosphatidylcholine monolayer were considered for oriented Fab' fragments immobilization. ${ }^{22}$

For oligonucleotide probes, the easiest way is to attach biotin at the end of the nucleic acid strand and form a very stable complex with avidin (streptavidin) covalently bound to the piezosensor surface. Low-cost silver-based piezosensors were protected with polystyrene and photobiotin was bound by UV-irradiation followed by avidin layer deposition..$^{23}$ Alternatively, thiol-tagged oligonucleotides can be self-assembled on the sensing surface. ${ }^{24}$ However, for peptide nucleic acids (PNA) as probes, immobilization through the streptavidin attached on a biotinylated phospholipid bilayer was much more efficient compared to self-assembled thiolated probes..$^{25}$ Electropolymerizable pyrrole-oligonucleotides were reported as suitable approach for hybridization sensors. ${ }^{26}$ An interesting dendritic nucleic acid probes were tested with piezosensors. ${ }^{27}$ Electrostatically bound multilayers were also investigated. ${ }^{28}$

For recombinant proteins containing oligohistidine tag, the metal affinity complexation with nickel ions and surface-attached nitrilotriacetic acid as a ligand is promising way for a reversible immobilization.

\section{Applications}

The piezoelectric biosensors were successfully used for assays of many different analytes as already reviewed in the literature. ${ }^{29}$ The working formats include direct, competitive and displacement assays. Large analytes (proteins, viruses and bacteria) can be measured directly after binding to the immobilized bioreceptor (e.g. antibody). An improved response is obtained through sandwich formation with suitable antibodies, which might be even attached to heavy tags functioning as enhancers of the measured signal. An overview of selected bioanalytical assays based on piezoelectric sensors is summarized in Table 1.

\subsection{Detection of viruses, bacteria and other cells}

Piezoelectric immunosensors suitable for detection of viruses and bacteria associated with acute diarrhea ${ }^{30}$ demonstrated detection limits of $10^{6}$ microorganisms per $\mathrm{mL}$. Herpes simplex viruses type 1 and 2, varicella-zoster virus, Epstein-Barr virus and cytomegalovirus were all detected from $10^{4}$ viruses per $\mathrm{mL}$ using direct assay. ${ }^{31} \mathrm{In}$ the case of detection of hepatitis A and B viruses, ${ }^{32}$ detection limits were $10^{5}$ per $\mathrm{mL}$. Sensor based on the DNARNA hybridization was employed for the detection of two plant orchid viruses, Cymbidium mosaic virus (CymMV) and Odontoglossum ringspot virus (ORSV). Specific 
Table 1. Biosensors based on piezoelectric quartz crystals

\begin{tabular}{|c|c|c|c|}
\hline Analyte & Assay principle and description & LOD & Ref. \\
\hline microorganisms & & (cells $\mathrm{mL}^{-1}$ ) & \\
\hline herpes viruses & direct immunosensor, Ab linked to Protein A & $5 \cdot 10^{4}$ & 31 \\
\hline Chlamydia trachomatis & direct immunosensor, $\mathrm{Ab}$ linked to anti-mouse $\mathrm{Ab} F(\mathrm{ab})_{2}$ & $260 \mathrm{ng} \mathrm{mL}^{-1}$ & 34 \\
\hline Escherichia coli & $\mathrm{PCR} /$ hybridization, immobilized lacZ gene as probe & 0.1 & 74 \\
\hline Mycobacterium tuberculosis & $\begin{array}{l}\text { direct immunosensor, Ab electrostatically adsorbed to } \\
\text { styrene-butadiene copolymer }\end{array}$ & 15 & 41 \\
\hline Proteus vulgaris and mirabilis & coagulation of gelatine with growing microorganism & $130 / 200$ & 128,129 \\
\hline Pseudomonas aeruginosa & $\begin{array}{l}\text { indirect immunosensor, displacement assay of the captured } \\
\text { antigen by bacteria }\end{array}$ & $10^{5}$ & 35 \\
\hline Salmonella enteritidis and paratyphi & $\begin{array}{l}\text { direct immunosensors, } \mathrm{Ab} \text { attached to electropolymerized } \\
\text { poly-m-aminophenol films }\end{array}$ & $5 \cdot 10^{5}$ & 38,40 \\
\hline Salmonella typhimurium & direct immunosensor, $\mathrm{Ab}$ linked to Protein $\mathrm{A}$ & $10^{6}$ & 127 \\
\hline Staphylococcus aureus & direct immunosensor & $5 \cdot 10^{5}$ & 36 \\
\hline Staphylococcus epidermidis & surface antigen agglutination & titer 0.005 & 58 \\
\hline Treponema pallidum & latex beads agglutination immunoassay & titer 0.02 & 39 \\
\hline proteins & & $\left(\mathrm{nmol} \mathrm{L} \mathrm{L}^{-1}\right)$ & \\
\hline C-reactive protein & latex beads agglutination immunoassay & 130 & 57 \\
\hline $\mathrm{C} 1$ and $\mathrm{C} 6$ complement factors & direct immunosensor, $\mathrm{Ab}$ crosslinked on PEI layer & 0.83 & 61,62 \\
\hline cholera toxin & $\begin{array}{l}\text { immunosensor, sandwich format, amplification with } \\
\text { ganglioside-modified liposomes containing POD label }\end{array}$ & 0.0001 & 126 \\
\hline ferritin & direct immunosensor, $\mathrm{Ab}$ crosslinked or attached to cysteamine SAM & 2.4 & 66 \\
\hline$\alpha$-fetoprotein & direct immunosensor, $\mathrm{Ab}$ crosslinked on cysteamine SAM & 1.5 & 65 \\
\hline hepatitis B surface antigen & direct immunosensor, $\mathrm{Ab}$ crosslinked on cysteamine SAM & 4.7 & 64 \\
\hline immunoglobulin $\mathrm{E}$ & affinity binding to ssDNA-based aptamer & 0.05 & 131 \\
\hline immunoglobulin $\mathrm{M}$ & $\begin{array}{l}\text { direct immunosensor, } \mathrm{Ab} \text { attached to } \mathrm{CNBr} \text {-activated, 2-hydroxyethyl } \\
\text { methacrylate }\end{array}$ & 5.5 & 56 \\
\hline insulin & immunosensor, sandwich format, $\mathrm{Ab}$ adsorbed & 0.17 & 68 \\
\hline staphylococcal enterotoxin B (SEB) & immunosensor, competitive format, SEB adsorbed on gold & 3.5 & 53 \\
\hline transferrin & agglutination assay, polyethyleneglycol-enhanced & 2.1 & 59 \\
\hline Small molecules & & $\left(\mu \mathrm{mol} \mathrm{L} \mathrm{L}^{-1}\right)$ & \\
\hline 2,4-dichlorophenoxyacetic acid & immunosensor, competitive format & 0.001 & 88 \\
\hline 2,4-dichlorophenoxyacetic acid & direct immunosensor, crosslinked $\mathrm{Ab}$ & 0.023 & 95 \\
\hline acetylcholine & coupled enzyme reactions, $\mathrm{AChE} / \mathrm{ChOD} / \mathrm{HRP}$ & 10 & 125 \\
\hline aminoantipyrine & molecularly imprinted polymer & 0.02 & 94 \\
\hline atrazin & immunosensor, competitive format & 0.0005 & 87 \\
\hline carbaryl & enzyme inhibition, immobilized AChE, ChOD, POD & 3 & 130 \\
\hline cocaine & direct immunosensor, $\mathrm{Ab}$ linked to Protein $\mathrm{G}$ & 33 & 81 \\
\hline cocaine & $\begin{array}{l}\text { immunosensor, competitive format, benzoylecgonine linked to } \\
11 \text {-mercaptoundecanoic acid based SAM }\end{array}$ & 0.0001 & 123 \\
\hline cortisol & direct immunosensor, $\mathrm{Ab}$ linked to Protein $\mathrm{A}$ & 100 & 80 \\
\hline$\beta$-estradiol & immobilized estrogen response element captures receptor-estradiol complex & 10 & 82 \\
\hline fructose & complexation with immobilized aminophenyl boronic acid & 550 & 85 \\
\hline$\beta$-indole acetic acid & immunosensor, competitive format & 0.003 & 84 \\
\hline nicotine & molecularly imprinted polymer & 0.025 & 124 \\
\hline paracetamol & molecularly imprinted polymer & 0.005 & 93 \\
\hline paraoxon & enzyme inhibition, immobilized cholinesterase & 0.05 & 50 \\
\hline polyaromatic hydrocarbons & immunosensor, competitive format & 0.01 & 89 \\
\hline terpenes & molecularly imprinted polymer & 1.3 & 91 \\
\hline
\end{tabular}

Abbreviations: Ab antibody; AChE acetylcholinesterase; ChOD choline oxidase; PCR polymerase chain reaction; PEI polyethylene imine; POD peroxidase; SAM self-assembled monolayer; titer indicates dillution of serum. 
oligonucleotide probes modified with a mercaptohexyl group at the 5'-phosphate end were directly immobilized and exposed to test solutions containing viral RNA; $10 \mathrm{ng}$ $\mathrm{mL}^{-1}$ of viral particles was successfully detected in crude plant extracts. ${ }^{33}$

A direct assay format was reported for Chlamydia trachomatis. ${ }^{34}$ The anti-surface lipopolysacharide $\mathrm{Ab}$ was attached to the sensor through anti-mouse $F(a b$ ') fragment immobilized to cystamine monolayer using sulfosuccinylimidyl 4-( $p$-maleimidophenyl)butyrate; $260 \mathrm{ng} \mathrm{mL}^{-1}$ was detected in urine. Detection of Pseudomonas aeruginosa in milk and diary samples employed displacement format, ${ }^{35}$ which allowed to detect ${ }^{36}$ $10^{5}$ cells per mL. Staphylococcus aureus was detected from $5 \times 10^{5}$ cells per mL. Piezoelectric immunosensor for Listeria monocytogenes was reported ${ }^{37}$ A direct sensor for Salmonella enteritidis ${ }^{38}$ was made by immobilizing antibodies on the divinylsulphone activated poly- $m$ aminophenol film; sensor was able to detect $10^{5}$ cells per $\mathrm{mL}$ within $25 \mathrm{~min}$.

Convenient approaches employed latex agglutination in the presence of microorganisms, generating large viscoelastic changes on the sensing surface. Such format was reported for Treponema pallidum in serum. ${ }^{39}$ Electropolymerized layer for antibody attachment was reported for Salmonella paratyphi detection ${ }^{40}$ at $10^{5}$ cells $\mathrm{mL}^{-1}$. Styrene-butadiene-styrene block copolymer was selected as a new membrane material to immobilize antibody used for detection of Mycobacterium tuberculosis. ${ }^{41}$ Plasma-polymerized ethylenediamine film was employed for immobilization of antibodies against Alexandrium affine, the red tide causing plankton. ${ }^{42}$

Several sensors were designed for blood cells. Human erythrocytes were measured using anti-glycophorin A antibody attached to the piezosensor with the limit of detection at 1000 cells per $\mathrm{mL}$ in whole blood. ${ }^{43}$ Similar sensors employed anti CD 3 gp Mr 19-29 kDa antibody for detection of human T-lymphocytes starting from 5000 cells $/ \mathrm{mL}$ of blood, ${ }^{44}$ and anti CD 18 antibody for granulocytes. ${ }^{45}$

\subsection{Determination of proteins}

A large group of papers is dealing with detection of antibodies present in serum after exposure to toxic agents. Thus, anti human immunodeficiency virus antibodies were detected in serum with selectivity comparable to ELISA. ${ }^{46}$ Similarly, respiratory syndrome virus infection ${ }^{47}$ and African swine fever disease ${ }^{48}$ were identified in porcine sera and Salmonella enteritidis in chicken meat and egg. ${ }^{49}$ Detection of antibodies against the African swine fever virus was realized using the recombinant viral attachment protein $\mathrm{p} 12$; an enhanced response was achieved using peroxidase label and 4-chloro-1-naphthol as substrate leading to insoluble product precipitating at the sensing surface. ${ }^{50}$ Exposure to Schistosoma japonium was detected in rabbit serum..$^{51}$ Assay of the staphylococcal enterotoxin C-2 compared different antibody immobilization approaches ${ }^{52}$ the enterotoxin $\mathrm{B}^{53}$ (SEB) was detected, too.

The latex agglutination immunoassay ${ }^{54}$ was used for detection of rheumatoid factor,,${ }^{55}$ human $\operatorname{IgM},{ }^{56}$ and C-reactive protein. ${ }^{57}$ Staphylococcus epidermidis agglutination with the corresponding antibody served for identification of sera infected with the microorganism. ${ }^{58}$ Poly(ethylene glycol)-enhanced agglutination assay of transferrin in human serum ${ }^{59}$ provided limit of detection at $2 \mathrm{nmol} \mathrm{L}^{-1}$.

Piezoelectric immunosensors (for review see ${ }^{60}$ ) were able to detect directly a wide range of clinically important analytes: complement inhibitors $\mathrm{C} 1^{61}$ and $\mathrm{C} 6,{ }^{62}$ factor $\mathrm{B},{ }^{63}$ hepatitis B surface antigen, ${ }^{64} \alpha$-fetoprotein ${ }^{65}$ and ferritin ${ }^{66}$ in serum, immunoglobulin E $\left(5-300 \mathrm{IU} \mathrm{mL}^{-1}\right){ }^{67}$ Sandwich assay for insulin ${ }^{68}$ exhibited limit of detection at $1 \mathrm{ng} \mathrm{mL}^{-1}$.

\subsection{Assays of nucleic acids}

Piezosensors were applied for the monitoring of hybridization quite early, ${ }^{69}$ for reviews see works of Mickelsen and Tombelli et al. ${ }^{70}$ Recently, a novel concept of a gene sensor employed primer extension after hybridization with template resulting in a real-time measurement format. ${ }^{71}$ Hybridization of the biotinylated 25-mer oligonucleotide probe (linked to neutravidinmodified piezosensor) with complementary, noncomplementary and single-base mutated 25-mer targets were monitored at ambient and elevated temperature, the latter allowing detection of single-base mutations. ${ }^{72}$

It is convenient to amplify the target DNA sequence using the polymerase chain reaction prior to the piezosensor measurement. In this way, genotypes of human apolipoprotein E were determined. ${ }^{73} \mathrm{Few}$ Escherichia coli bacteria can be detected in $100 \mathrm{~mL}$ of water, ${ }^{74}$ detection of Aeromonas hydrophila was also reported. ${ }^{75}$

Various signal amplification strategies were developed to improve sensitivity of detection. Anti-dsDNA antibodies were reported to amplify signal during detection of the Tay-Sachs disease. ${ }^{24}$ Binding of biotinylated liposomes, ${ }^{76}$ deposition of gold nanoparticles ${ }^{77}$ and even intercalation of actinomycine $\mathrm{D}$ bound to magnetic nanoparticles ${ }^{78}$ were another ways for signal increase. Recently, piezoelectric biosensors were considered as a convenient tool for detection of genetically modified organisms (GMO). ${ }^{79}$ 


\subsection{Measurement of small molecules}

For small molecules as pesticides, drugs and hormones, the competitive measurement is needed in order to achieve measurable changes of frequency; the analyte is mixed with antibody to form immunocomplexes and the remaining free binding sites of the antibody can subsequently interact with sensing surface modified with a derivative of the analyte.

Cortisol immunoassay ${ }^{80}$ exhibited limit of detection at $100 \mathrm{nmol} \mathrm{L}^{-1}$, cocaine was detected at $33 \mathrm{nmol} \mathrm{L}^{-1}$ using the anti-benzoylecgonine antibody. ${ }^{81}$ For $\beta$-estradiol, the specific receptor was immobilized on the surface ${ }^{82}$ providing detection limit of $8 \mathrm{nmol} \mathrm{L}^{-1}$. A cholestyramine resin-coated piezosensors were used for convenient detection of bile acids (e.g. taurodeoxycholate at

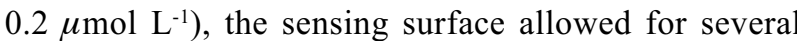
hundredths of regenerations. ${ }^{83} \beta$-Indolyl acetic acid was measured competitively ${ }^{84}$ from 3 nmol $\mathrm{L}^{-1}$. The aminophenylboronic acid-modified surface served for measurement of fructose ${ }^{85}$ starting from $0.5 \mathrm{mmol} \mathrm{L}^{-1}$.

The early described immunosensor for the herbicide atrazine employing the drying approach ${ }^{86}$ stimulated other works describing assay of atrazine ${ }^{87}$ and other pesticides ${ }^{88}$ in flow-through formats. Assay for polyaromatic hydrocarbons was designed using anti benzo[a]pyrene-specific antibody and competitive format. ${ }^{89}$ For non-polar analytes, the presence of organic solvents can improve performance of piezoelectric immunosensors. ${ }^{90}$ For this purpose, the artificial molecularly imprinted polymers (MIP) represent robust and stable recognition elements, as demonstrated by the detection of terpenes. ${ }^{91}$ Molecular recognition sites for the nucleotides adenosine 5'- monophosphate, guanosine 5'-monophosphate, cytosine 5'- monophosphate and uridine 5'-monophosphate were imprinted in an acrylamide-aminophenylboronic acid copolymer on the piezosensor surface providing novel way for sequencing of nucleic acids. ${ }^{92}$ The reported MIP layers on piezosensors were also applied for measurement of paracetamol $^{93}$ and aminoantipyrine. ${ }^{94}$

Recently several papers described detection of small molecules using direct assay format; ${ }^{95}$ in fact, the measured frequency changes do not correspond to the theoretically bound material (missing mass effect). Instead, the immobilized bioligands undergo conformation change upon complex formation with the small analyte. This results in viscoelastic changes of the surface-attached layers and this process is measured by the piezosensor with a high sensitivity.

\subsection{Affinity studies using piezoelectric sensors}

The technique demonstrated above was used to characterize several monoclonal ${ }^{96}$ as well as recombinant $t^{97}$ antibodies. Validation of results obtained using piezosensors and resonant mirror-based sensors were reported. ${ }^{98}$ In the case of polyclonal antibodies, exact kinetic parameters are not obtained; nevertheless, the quantitative comparison of different antibody products is possible. Moreover, fast determination of affinities is useful during screening and development of antibodies. The kinetic parameters enable to select the most suitable antibody for the planned use when several monoclonals are available. Of course, qualitative results from affinity studies are very important, too.

A detailed kinetic characterization of berberine interaction with albumin ${ }^{99}$ provided moderate affinity described by $K_{a}$ of $4 \times 10^{4} \mathrm{~L} \mathrm{~mol}^{-1}$. The affinity of the maltose binding protein-nitro reductase fusion (MBP-NR) to electropolymerized films of N-(3-pyrrol-1- ylpropyl)4,4'-bipyridinium (PPB) has been studied. ${ }^{100}$ Permeability of bacterial cell walls was studied using interaction of peptides representing different regions of human bactericidal/permeability-increasing protein (BPI) and polymyxin B (PmB) with lipopolysaccharide attached to the piezosensor. ${ }^{101}$ Piezosensors were conveniently used for kinetic characterization of isolates from combinatorial phagemid libraries. Kinetic rate constants for interaction between human pancreatic secretory trypsin inhibitor and Legionella pneumophila were determined in this way. ${ }^{102}$

For epitope mapping, variability of amino acids in the binding site region of structural protein VP1 of parvovirus B19 was monitored using piezosensors providing the corresponding equilibrium dissociation constants. ${ }^{103}$ Systematic ligand-binding studies of the interaction between steroids (17 testosterone and $\beta$-estradiol derivatives) and anti-steroid antibodies were performed to assess the effect of biotinylation of the steroid molecule in different positions. ${ }^{104}$

Living endothelial cells were cultured on the piezosensor surface as the biological signal transduction element. Nocodazole, a known microtubule binding drug, alters the cytosceletal properties of living cells resulting in cell contact breaks measured as frequency changes. ${ }^{105}$

Kinetics of DNA hybridization was monitored using the network analysis measuring method. ${ }^{106}$ Studies of metal complex binding to nucleic acid employed DNA layers attached electrostatically to methylated 4-thiopyridine layers self-assembled on the gold surface, ${ }^{107} K_{a}$ was equal to $2.0 \times 10^{4} \mathrm{~L} \mathrm{~mol}^{-1}$ for hexaammineruthenium(III) complex. ${ }^{108}$ Similar study was carried out also for the tris(2,2'- bipyridyl)cobalt(III) complex. DNA oxidative damage induced by the vitamin C-Fe (III) system represented another convenient application. ${ }^{109}$ Interactions 
of drugs (nogalamycin ${ }^{110}$ and platinum-based anticancer ${ }^{111}$ ) with DNA open another important area.

Piezosensor was used to measure the equilibrium constant and binding kinetics of a PCN antigen to doublestranded DNA model fragments. The antigen, which is negatively charged on its outer side and positively on its inside, was shown to slip along the DNA fragment. ${ }^{12}$ Similar study was carried out for histone F3 binding. ${ }^{113} \mathrm{~A}$ sequence-specific binding of bZIP 56-mer peptides (having both the basic region for binding and the leucine zipper region for dimerization) to the DNA strand on the $27 \mathrm{MHz}$ piezosensor was observed and kinetically characterized. ${ }^{114}$

Interaction of nucleic acids with cleaving enzymes ${ }^{115}$ can be followed by piezosensors with high sensitivity. In this way, multilayers composed of bis-biotinylated dsDNA and streptavidin were shown to be bioactive as evidenced by cleavage with restriction endonuclease. ${ }^{116}$ However, prolongation of DNA chain using polymerase can be monitored, too. ${ }^{117}$

Specific binding of lectin - peanut agglutinin to ganglioside G(M1)-doped solid supported lipid bilayers ${ }^{118}$ exhibited $K_{a}$ of $8.3 \times 10^{5} \mathrm{~L} \mathrm{~mol}^{-1}$. Monosialoganglioside monolayers were applied for binding of wheat germ agglutinin. ${ }^{119}$ Adsorption behavior of artificial glycoconjugate polymers with different saccharide chain lengths and with different backbone structures ${ }^{120}$ was investigated as a model saccharide-based biorecognition element.

Stable solid-supported bilayers consisting of an octanethiol monolayer chemisorbed on gold and a physisorbed phospholipid monolayer varying in its lipid composition as the outermost layer were used for studies with the Raf-Ras binding domain and the cysteine-rich domain Raf-C1 fused to maltose binding protein, implying mostly electrostatic character of interaction. ${ }^{121}$

The degradation of polymeric layers coated on surface of piezosensors represents convenient route for detection of the corresponding hydrolases; polyhydroxybutyrate depolymerase was able to degrade poly(ester) films. ${ }^{122}$

\section{Conclusions}

For a long time, piezoelectric systems were rather neglected by the biosensor community; the common feeling was that these devices are not sensitive enough compared to other types of transducers. As theoretical backgrounds for operation of piezosensors in liquids become completed and many successful applications were reported in the literature, this situation is changing gradually. This change of attitude was fully evident at the first conference dedicated to piezoelectric and acoustic sensors - QCM 2002 in Brighton, UK.
The aim of this review was to demonstrate different types of analytes measurable with piezosensors using bioanalytical assay formats. The piezoelectric biosensors represent a convenient tool for fast and simple determination of viruses, bacterial and other cells, proteins, nucleic acids and small molecules as drugs, hormones and pesticides. Usually, no additional unstable reagents are required for the analysis. In addition to the traditionally interpreted mass changes, additional sensing approaches appeared. The presence of analyzed molecules initiates agglutination reactions and conformation changes of attached biolayers. The associated viscoelastic effects provide novel ways to improved sensitivity of measurements.

Piezosensors are also useful as a research tool for biochemistry and biology. The direct label-free and realtime monitoring of affinity interactions with piezosensors represents an economic alternative to the overpriced optical systems based on the surface plasmon resonance phenomenon. The theoretical background for determination of kinetic rate and equilibrium constants was presented here and the approach was demonstrated on the model interaction of antibody with the corresponding antigen (protein secalin). In this way, valuable characteristics of affinity binding reaction can be obtained easily and quickly. ${ }^{123-131}$

\section{References}

1. Grate, J. W.; Martin, S. J.; White, R. M.; Anal. Chem. 1993, 65, A940; A987.

2. Sauerbrey, G.; Z. Phys. 1959, 155, 206.

3. Henry, C.; Anal. Chem. 1996, 68, 625A; O'Sullivan, C. K.; Guilbault, G.G.; Biosens. Bioelectron. 1999, 14, 663.

4. Nomura, T.; Watanabe, M.; West, T. M.; Anal. Chim. Acta 1985, 175, 107.

5. Texas Instruments; SN74LS320 Crystal-Controlled Oscillators, 1981, D2418, 3-801; Skládal, P.; Horáèek, J.; Anal. Lett. 1999, 32,1519 .

6. Hepel, M.; Interfacial Electrochemistry, M. Dekker: New York, 1999, vol. 34, p. 599.

7. Skládal, P.; Minunni, M.; Mascini, M.; Koláé, V.; Fránek, M.; J. Immunol. Meth. 1994, 176, 117.

8. O'Shannessy, D.J.; Curr. Opin. Biotechnol. 1994, 5, 65.

9. Morton, T. A.; Myszka, D. G.; Chaiken, I. M.; Anal. Biochem. 1995, 227, 176.

10. Hermanson, G. T.; Mallia A. K.; Smith, P. K.; Immobilized Affinity Ligand Techniques, Academic Press: San Diego, 1992.

11. Storri, S.; Mascini, M.; Santoni, T.; Minunni, M.; Biosens. Bioelectron. 1998, 13, 347; Tombelli, S.; Mascini, M.; Anal. Lett 2000, 33, 2129. 
12. Suri, C. R.; Mishra, G. C.; Biosens. Bioelectron. 1996, 11, 1199.

13. Rickert, J.; Weiss, T.; Kraas, W.; Jung, G.; Gopel, W.; Biosens. Bioelectron. 1996, 11, 591.; Kim, H. J.; Kwak, S.; Kim, Y. S.; Seo, B. I.; Kim, E. R.; Lee, H.; Thin Solid Films 1998, 329, 191; Vaughan, R. D.; O’Sullivan, C. K.; Guilbault, G. G.; Fresenius J. Anal. Chem. 1999, 364, 54.

14. Geddes, N. J.; Paschinger, E. M.; Furlong, D. N.; Ebara, Y.; Okahata, Y.; Than, K. A.; Edgar, J. A.; Sens. Actuators B 1993, 17,125 .

15. Ebersole, R. C.; Miller, J. A.; Moran, J. R.; Ward, M. D.; J. Am. Chem. Soc. 1990, 112, 3239.

16. Damrongchai, N.; Yun, K.; Kobatake, E.; Aizawa, M.; J. Biotechnol. 1997, 55, 125.

17. Ren, X. Z.; Kobatake, E.; Aizawa, M.; Analyst 2000, 125 , 669.

18. Ghafouri, S.; Thompson, M.; Langmuir 1999, 15, 564.

19. Caruso, F.; Niikura, K.; Furlong, D. N.; Okahata, Y.; Langmuir 1997, 13, 3427.

20. Babacan, S.; Pivarnik, P.; Letcher, S.; Rand, A. G.; Biosens. Bioelectron. 2000, 15, 615.

21. Dubrovskii, T. B.; Erokhin, V. V.; Kauyskina, R. L.; Biol. Membranes 1992, 9, 88.; Barraud, A.; Perrot, H.; Billard, V.; Martelet, C.; Therasse, J.; Biosens. Bioelectron. 1993, 8, 39.

22. Vikholm, I.; Albers, W. M.; Valimaki, H.; Helle, H.; Thin Solid Films 1998, 329, 643.

23. Su, X. D.; Biochem. Biophys. Res. Commun. 2002, $290,962$.

24. Bardea, A.; Dagan, A.; Willner, I.; Anal. Chim. Acta 1999 , 385, 33; Patolsky, F.; Lichtenstein, A.; Willner, I.; Nat. Biotechnol. 2001, 19, 253.

25. Hook, F.; Ray, A.; Norden, B.; Kasemo, B.; Langmuir 2001, 17,8305 .

26. Lassalle, N.; Roget, A.; Livache, T.; Mailley, P.; Vieil, E.; Talanta 2001, 55, 993.

27. Wang, J.; Jiang, M.; Nilsen, T. W.; Getts, R. C.; J. Am. Chem. Soc. 1998, 120, 8281 .

28. Zhou, X. C.; Huang, L. Q.; Li, S. F. Y.; Biosens. Bioelectron. 2001, 16, 85 .

29. Suleiman, A. A.; Guilbault, G. G.; Analyst 1994, 119, 2279; Bunde, R. L.; Jarvi, E. J.; Rosentreter, J. J.; Talanta 1998, 46, 1223.

30. Konig, B.; Gratzel, M.; Anal. Lett. 1993, 26, 1567.

31. Konig, B.; Gratzel, M.; Anal. Chem. 1994, 66, 341; Susmel, S.; O’Sullivan, C. K.; Guilbault, G. G.; Enzyme Microb. Technol. 2000, 27, 639.

32. Konig, B.; Gratzel, M.; Anal. Chim. Acta 1995, 309, 19; Zhou, X. D.; Liu, L. J.; Hu, M.; Wang, L. L.; Hu, J. M.; J. Pharm. Biomed. Anal. 2002, 27, 341.

33. Eun, A. J. C.; Huang, L. Q.; Chew, F. T.; Li, S. F. Y.; Wong, S. M.; Phytopathology 2002, 92, 654.

34. Ben-Dov, I.; Willner, I.; Zisman, E.; Anal. Chem., 1997, 69, 3506 .
35. Bovenizer, J. S.; Jacobs, M. B.; O’Sullivan, C. K.; Guilbault, G. G.; Anal. Lett. 1998, 31, 1287; Kaspar, M.; Stadler, H.; Weiss, T.; Ziegler, C.; Fresenius J. Anal. Chem. 2000, 366, 602 .

36. Le, D.; He, F. J.; Jiang, T. J.; Nie, L. H.; Yao, S. Z.; J. Microbiol. Meth. 1995, 23, 229.

37. Jacobs, M. B.; Carter, R. M.; Lubrano, G. J.; Guilbault, G. G.; Am. Lab. 1995, 27, 26.

38. Fung, Y. S.; Si, S. H.; Zhu, D. R.; Talanta 2000, 51, 151.

39. Aizawa, H.; Kurosawa, S.; Tanaka, M.; Wakida, S.; Talib, Z. A.; Park, J. W.; Yoshimoto, M.; Muratsugu, M.; Hilborn, J.; Miyake, J.; Tanaka, H.; Mater. Sci. Eng. C Biomimetic Supramol. Syst. 2001, 17, 127.

40. Si, S. H.; Ren, F. L.; Cheng, W.; Yao, S. Z.; Fresenius J. Anal. Chem. 1997, 357, 1101.

41. He, F. J.; Zhang, L. D.; Zhao, J. W.; Hu, B. L.; Lei, J. T.; Sens. Actuators B 2002, 85, 284.

42. Nakanishi, K.; Masao, A.; Sako, Y.; Ishida, Y.; Muguruma, H.; Karube, I.; Anal. Lett. 1996, 29, 1247.

43. Konig, B.; Gratzel, M.; Anal. Chim. Acta 1993, 276, 329.

44. Konig, B.; Gratzel, M.; Anal. Chim. Acta 1993, 281, 13.

45. Konig, B.; Gratzel, M.; Anal. Lett. 1993, 26, 2313.

46. Kosslinger, C.; Drost, S.; Aberl, F.; Wolf, H.; Fresenius J. Anal. Chem. 1994, 349, 349.

47. Su, X. D.; Li, S. F. Y.; Liu, W.; Kwang, J.; Analyst 2000, 125, 725 .

48. Uttenthaler, E.; Kosslinger, C.; Drost, S.; Anal. Chim. Acta 1998, 362, 91 .

49. Su, X. D.; Low, S.; Kwang, J.; Chew, V. H. T.; Li, S. F. Y.; Sens. Actuators B 2001, 75, 29.

50. Abad, J. M.; Pariente, F.; Hernandez, L.; Lorenzo, E.; Anal. Chim. Acta. 1998, 368, 183.

51. Wu, Z. Y.; Shen, G. L.; Li, Z. Q.; Wang, S. P.; Yu, R. Q.; Anal. Chim. Acta 1999, 398, 57.

52. Gao, Z. X.; Chao, F. H.; Chao, Z.; Li, G. X.; Sens. Actuators B 2000, 66, 193

53. Harteveld, J. L. N.; Nieuwenhuizen, M. S.; Wils, E. R. J.; Biosens. Bioelectron. 1997, 12, 661.

54. Muratsugu, M.; Kurosawa, S.; Ghourchian, H. O.; Kamo, N.; Curr. Topics Anal. Chem. 1998, 55.

55. Ghourchian, H. O.; Kamo, N.; Hosokawa, T.; Akitaya, T.; Talanta 1994, 41, 401.

56. Chu, X.; Shen, G. L.; Xie, F. Y.; Yu, R. Q.; Anal. Lett. 1997, 30, 1783.

57. Aizawa, H.; Kurosawa, S.; Ogawa, K.; Yoshimoto, M.; Miyake, J.; Tanaka, H.; Sens. Actuators B 2001, 76, 173.

58. Pavey, K. D.; Ali, Z.; Olliff, C. J.; Paul, F.; J. Pharm. Biomed. Anal. 1999, 20, 241.

59. Wu, Z. Y.; Shen, G. L.; Xie, L. J.; Yu, R. Q.; Sens. Actuators B 2000, 71, 99.

60. O'Sullivan, C. K.; Vaughan, R.; Guilbault, G. G.; Anal. Lett. 1999, 32, 2353. 
61. Liu, L.; Hu, J. M.; Wang, L. L.; Liu, L. J.; Zhou, X. D.; Fresenius J. Anal. Chem. 2001, 369, 483.

62. Hu, J. M.; Liu, L. J.; Danielsson, B.; Zhou, X. D.; Wang, L. L.; Anal. Chim. Acta 2000, 423, 215.

63. Liu, L. J.; Hu, J. M.; Pei, R. J.; Hu, Y.; Chem. J. Chin. Univ. Chin. 1999, 20, 887.

64. Chen, Z. Z.; Wang, K. M.; Chen, Y. K.; Xiao, D.; Yang, X. H.; Shao, G. Q.; Chem. J. Chin. Univ. 2002, 23, 1044.

65. Chou, S. F.; Hsu, W. L.; Hwang, J. M.; Chen, C. Y.; Clin. Chem. 2002, 48, 913.

66. Chou, S. F.; Hsu, W. L.; Hwang, J. M.; Chen, C. Y.; Anal. Chim. Acta. 2002, 453, 181.

67. Su, X. D.; Chew, F. T.; Li, S. F. Y.; Anal. Biochem. 1999, 273, 66.

68. Saha, S.; Raje, M.; Suri, C. R.; Biotechnol. Lett. 2002, 24, 711.

69. Fawcett, C.; Evans, J. A.; Anal. Lett. 1988, 21, 1099.; Campbell, N. F.; Evans, J. A.; Fawcett, N. C.; Biochem. Biophys. Res. Commun. 1993, 196, 858.

70. Mickelsen, S. R.; Electroanalysis 1996, 8, 15; Tombelli, S.; Marrazza, G.; Mascini, M.; Int. J. Environ. Anal. Chem. 2001, 80, 87 .

71. Chen, Y. H.; Song, J. D.; Li, D. W.; Sci. China Ser. C. 1997, 40, 463.

72. Furtado, L. M.; Thompson, M.; Analyst 1998, 123, 1937.

73. Marrazza, G.; Tombelli, S.; Mascini, M.; Manzoni, A.; Clin. Chim. Acta. 2001, 307, 241.

74. Mo, X. T.; Zhou, Y. P.; Lei, H.; Deng, L.; Enzyme Microb. Technol. 2002, 30, 583.

75. Tombelli, S.; Mascini, M.; Sacco, C.; Turner, A. P. F.; Anal. Chim. Acta 2000, 418, 1 .

76. Patolsky, F.; Lichtenstein, A.; Willner, I.; J. Am. Chem. Soc. 2000, 122, 418.

77. Weizmann, Y.; Patolsky, F.; Willner, I.; Analyst 2001, 126, 1502.

78. Zhang, S. L.; Peng, T. Z.; Yang, C. F.; J. Electroanal. Chem. 2002, 522, 152.

79. Minunni, M.; Tombelli, S.; Mariotti, E.; Mascini, M.; Fresenius J. Anal. Chem. 2001, 369, 589; Minunni, M.; Tombelli, S.; Pratesi, S.; Mascini, M.; Piatti, P.; Bogani, P.; Buiatti, M.; Mascini, M.; Anal. Lett. 2001, 34, 825.

80. Attili, B. S.; Suleiman, A. A.; Anal. Lett. 1995, 28, 2149.

81. Attili, B. S.; Suleiman, A. A.; Microchem. J. 1996, 54, 174.

82. Mo, Z. H.; Long, X. H.; Fu, W. L.; Anal. Commun. 1999, 36, 281.

83. Chance, J. J.; Purdy, W. C.; Anal. Chem. 1996, 68, 3104.

84. Li, J.; Wu, Z. Y.; Xiao, L. T.; Zeng, G. M.; Huang, G. H.; Shen, G. L.; Yu, R. Q.; Anal. Sci. 2002, 18, 403.

85. Lau, O. W.; Shao, B.; Lee, M. T. W.; Anal. Chim. Acta 2000, 403, 49.

86. Guilbault, G. G.; Hock, B.; Schmid, R.; Biosens. Bioelectron. 1992, 7, 411.

87. Steegborn, C.; Skládal, P.; Biosens. Bioelectron. 1997, 12, 19.
88. Horá1ek, J.; Skládal, P.; Anal. Chim. Acta 1997, 347, 43.

89. Liu, M.; Li, Q. X.; Rechnitz, G. A.; Anal. Chim. Acta 1999, 387, 29.

90. Horá1ek, J.; Skládal, P.; Anal. Chim. Acta 2000, 412, 37.

91. Percival, C. J.; Stanley, S.; Galle, M.; Braithwaite, A.; Newton, M. I.; McHale, G.; Hayes, W.; Anal. Chem. 2001, 73, 4225.

92. Sallacan, N.; Zayats, M.; Bourenko, T.; Kharitonov, A. B.; Willner, I.; Anal. Chem. 2002, 74, 702.

93. Tan, Y. G.; Zhou, Z. L.; Wang, P.; Nie, L. H.; Yao, S. Z.; Talanta 2001, 55, 337.

94. Tan, Y. G.; Nie, L. H.; Yao, S. Z.; Analyst 2001, 126, 664.

95 Halámek, J.; Hepel, M.; Skládal, P.; Biosens. Bioelectron. 2001, 16, 253.

96. Horá1ek, J.; Skládal, P.; Anal. Chim. Acta 1997, 347, 43.

97. Horá1ek, J.; Skládal, P.; Food Agric. Immunol. 1998, 10, 363.

98. Skládal, P.; Horá1ek, J.; Anal. Lett. 1999, 32, 1519.

99. Mao, Y. A.; Wei, W. Z.; He, D. L.; Nie, L. H.; Yao, S. Z.; Anal. Biochem. 2002, 306, 23.

100. Takada, K.; Naal, Z.; Park, J. H.; Shapleigh, J. P.; Bernhard, S.; Batt, C. A.; Abruna, H. D.; Langmuir 2002, 18, 4892.

101. Chang, H. C.; Yang, C. C.; Yeh, T. M.; Anal. Chim. Acta 1997, $340,49$.

102. Decker, J.; Weinberger, K.; Prohaska, E.; Hauck, S.; Kosslinger, C.; Wolf, H.; Hengerer, A.; J. Immunol. Meth. 2000, 233, 159.

103. Dorsch, S.; Kaufmann, B.; Schaible, U.; Prohaska, E.; Wolf, H.; Modrow, S.; J. Gen. Virol. 2001, 82, 191.

104. Kaiser, T.; Gudat, P.; Stock, W.; Pappert, G.; Grol, M.; Neumeier, D.; Luppa, P. B.; Anal. Biochem. 2000, 282, 173.

105. Marx, K. A.; Zhou, T. A.; Montrone, A.; Schulze, H.; Braunhut, S. J.; Biosens. Bioelectron. 2001, 16, 773.

106. Su, H.; Thompson, M.; Biosens. Bioelectron. 1995, 10, 329.

107. Aslanoglu, M.; Houlton, A.; Horrocks, B. R.; Analyst 1998, 123, 753

108. Zhou, A. H.; Xie, Q. J.; Zhang, Y. Y.; Nie, L. H.; Yao, S. Z.; Anal. Sci. 2000, 16, 467.

109. Guo, B.; Yuan, Y.; Wu, Y. H.; Xie, Q. J.; Yao, S. Z.; Anal. Biochem. 2002, 305, 139.

110. Pope, L. H.; Allen, S.; Davies, M. C.; Roberts, C. J.; Tendler, S. J. B.; Williams, P. M.; Langmuir 2001, 17, 8300.

111. Su, H. B.; Williams, P.; Thompson, M.; Anal. Chem. 1995, 67, 1010.

112. Furusawa, H.; Kitamura, Y.; Hagiwara, N.; Tsurimoto, T.; Okahata, Y.; Chem. Phys. Chem. 2002, 3, 446.

113. Niikura, K.; Nagata, K.; Okahata, Y.; Chem. Lett. 1996, 863.

114 Okahata, Y.; Niikura, K.; Sugiura, Y.; Sawada, M.; Morii, T.; Biochemistry 1998, 37, 5666.

115. Wang, J.; Jiang, M.; Paleèek, E.; Bioelectrochem. Bioenerg. 1999, 48, 477; Matsuno, H.; Furusawa, H.; Okahata, Y.; Chem. Commun. 2002, 470.

116. Ijiro, K.; Ringsdorf, H.; Birchhirschfeld, E.; Hoffmann, S.; Schilken, U.; Strube, M.; Langmuir 1998, 14, 2796. 
117. Niikura, K.; Matsuno, H.; Okahata, Y.; J. Am. Chem. Soc. 1998, 120,8537 .

118. Janshoff, A.; Steinem, C.; Sieber, M.; Galla, H. J.; Eur. Biophys. J. Biophys. Lett. 1996, 25, 105.

119. Sato, T.; Serizawa, T.; Ohtake, F.; Nakamura, M.; Terabayashi, T.; Kawanishi, Y.; Okahata, Y.; Biochim. Biophys. Acta Gen. Sub. 1998, 1380, 82.

120. Tsuchida, A.; Matsuura, K.; Kobayashi, K.; Macromol. Chem. Phys. 2000, 201, 2245.

121. Eing, A.; Janshoff, A.; Galla, H. J.; Block, C.; Steinem, C.; Chembiochem 2002, 3, 190.

122. Yamashita, K.; Aoyagi, Y.; Abe, H.; Doi, Y.; Biomacromolecules 2001, 2, 25.

123. Halámek, J.; Makower, A.; Skládal, P.; Scheller F. W.; Biosens. Bioelectron. 2002, 17, 1045.
124. Tan, Y. G.; Yin, J.; Liang, C. D.; Peng, H.; Nie, L. H.; Yao, S. Z.; Bioelectrochemistry 2001, 53, 141.

125. Alfonta, L.; Katz, E.; Willner, I.; Anal. Chem. 2000, 72, 927.

126. Alfonta, L.; Willner, I.; Anal.Chem. 2001, 73, 5287.

127. Babacan S.; Pivarnik, P.; Letcher, S.; Rand, A.; J. Food Sci. 2002, 67, 314.

128. Bao, L.; Deng, L.; Nie, L.; Yao, S.; Wei, W.; Biosens. Bioelectron. 1996, 11, 1193.

129. Bao, L. L.; Deng, L.; Nie, L. H.; Yao, S. Z.; Wei, W. Z.; Talanta 1996, 43, 675 .

130. Karousos, N. G.; Aouabdi, S.; Way, A. S.; Reddy, S. M.; Anal. Chim. Acta 2002, 469, 189.

131. Liss, M.; Petersen, B.; Wolf, H.; Prohaska, E.; Anal. Chem. 2002, 74, 4488. 